\title{
STAV A PERSPEKTIVY BÁDÁNÍ NOVOVĚKÉHO POHŘEBNÍHO RITU V ČECHÁCH
}

\author{
MARTIN OMELKA - OTAKARA ŘEBOUNOVÁ
}

\begin{abstract}
Abstrakt: V př́spěvku je na základě publikovaných archeologických lokalit provedeno hodnoceni stavu a perspektiv bádáni předevšim raně novověkého a novověkého pohrebního ritu na územi Čech (od konce 15. století do roku 1800). Autoři textu zároveň reagují na stále se zvyšujicí odbornou poptávku po mezioborové spolupráci v dané problematice a naznačuji nové možné směry výzkumu. Nedilnou soućástí studie je i soupis př́slušné publikované literatury vydané v Čechách po roce 2000.
\end{abstract}

Klíčová slova: Čechy-novověk-pohřbní ritus - devocionálie.

\section{The State and Perspectives of Research into Modern-Age Funeral Rites in Bohemia}

Abstract: This contribution assesses, on the basis of published archaeological sites, the state and perspectives of research into early modern-age and modern-age funeral rites in Bohemia (from the late 15th century until 1800). In addition, the authors respond to the growing specialist demand for interdisciplinary collaboration in respect to these issues and outline possible new directions of research. The study includes a list of literature on the subject published in this country after 2000.

Key words: Bohemia - modern age - burial rite-devotionalia.

\section{Vymezení termínu a časové osy}

Etapa novověku je v domácí archeologii chápána jako poměrně dlouhý časový úsek zahrnující období od konce 15 . století do roku 1800 , resp. až první poloviny 20 . století. V příspěvku se pokusíme vykreslit dosavadní stav a perspektivy bádání především v oblasti raně novověkého pohřebního ritu, pokládaného datačně tradičně do konce 15 . až poloviny 17 . století, a novověkého pohřebního ritu, spadajícího do let 1650-1800, v Čechách. ${ }^{1}$ Budeme se přitom opírat zejména o dosud vydané syntetizující práce a archeologické výzkumy jednotlivých českých lokalit publikované po roce 2000.

Pohřební ritus lze definovat jako soubor zvyklostí v nakládání s tělem zemřelého od okamžiku smrti po jeho uložení do hrobu. Pro období novověku se pro jeho identifikaci a dataci v terénu staly klíčovými faktory přítomnost/nepřítomnost pohřební výbavy a její charakter. $Z$ hlediska těchto kritérií lze v jeho vývoji podle našeho názoru rozlišit tři výrazněji se od sebe lišící etapy, jejichž ráz určovaly jednak kulturně-historické události, především změny konfesních poměrů, a jednak pokrok v technologii výroby.

První etapu lze vymezit obdobím mezi objevením amerického kontinentu (1492) a koncem trricetileté války (1648). Archeologicky je toto období bohužel nejhůře uchopitelné. Zpravidla nám splývá s obdobím vrcholné gotiky, a to z důvodu, že se v standardních hrobech objevuje, v obou časových úsecích, minimum datovatelné pohřební výbavy. Nicméně jde rovněž o období, kdy se křest’anská společnost v Evropě rozdělila do dvou konfesních táborů, což se záhy promítlo i do pohřebních zvyklostí. Začaly se od sebe oddělovat hroby katolíků a nekatolíků (Unger 2002, 41-43), vznikají i samostatné nekatolické hřbitovy. Pohřby prŕslušníků jednotlivých konfesí se navíc začínají lišit okázalostí a složením předmětů vkládaných do hrobu jako součást pohřební výbavy. Je proto otázkou, zda z pohledu pohřebního ritu neposunout časovou hranici $\mathrm{k}$ roku 1517, začátku reformace, jako je tomu např́íklad v Německu (Kenzler 2015, 148).

Naopak velice dobře můžeme archeologicky uchopit další etapu, kterou lze ztotožnit s obdobím probíhajícím od konce třicetileté války do zhruba první poloviny 80 . let 18 . století (1648-

1 Období raného novověku se v české archeologii tradičně klade do rozmezí konce 15 . až poloviny 17 . století. Období $1650-1800$ se označuje jako novověk. Celý tento časový úsek je předmětem studia tzv. postmedievální archeologie, na kterou navazuje archeologie novověku a archeologie současnosti. Období novověku rozděluje do dvou etap i české historické bádání, které pro časové rozmezí 1500-1650 užívá označení raný novověk a pro rozmezí 1650-1790/1800 novověk (Petráň a kol. 1995, 31). 
1781, resp. 1784). Pro území českého státu je v této fázi charakteristické, že zdejší nábožensky nesourodé obyvatelstvo, ve kterém ještě na počátku 17. století převažovalo obyvatelstvo nekatolického vyznání, bylo po ukončení třicetileté války v roce 1648 prakticky plošně rekatolizováno. Vládnoucí Habsburkové získali podle zásady „cuius regio, eius religio“ možnost prosadit si na svých državách katolickou konfesi, a proto po ukončení třicetileté války část evangelického obyvatelstva zemi opustila. Zbylá část obyvatel byla nucena na katolickou víru přestoupit. Také tyto okolnosti se následně promítly do pohřebních zvyklostí. Po roce 1648 až do konce 18. století převážná část pohřbů v Čechách vykazuje prvky katolického pohřebního ritu, ${ }^{2}$ nebo jde o pohřebiště židovská. ${ }^{3}$ Protestantské pohřební okrsky, běžné v našem prostředí do období před bitvou na Bílé hoře (1620), ${ }^{4}$ se opětovně začínají zakládat až po vydání tzv. tolerančního patentu Josefa II. v roce $1781 .{ }^{5}$ Charakteristickou součástí katolického pohřbu v tomto období byla důsledná aplikace pohřební výbavy složené přinejmenším z křiže, respektive krucifixu, a růžence nebo modlitební šňůry, zdobených zpravidla typově pestrou škálou drobných křižzvých přívěsků a náboženských medailonů (obr. 1). Složení pohřebního inventáře mohl doplňovat relikviár̆, škapulíř, modlitební kniha, pohřební věnec nebo pohřební koruna. Zemřelí byli ukládáni v natažené poloze na zádech tak, aby obvykle v rukách třímali odpustkový kř́iž (krucifix) s růžencem, v městském prostředí, jak dokládají dosud provedené výzkumy (viz níže), se upřednostňovaly pohřby $\mathrm{v}$ rakvích.

To, že ve velké části hrobových kontextů z období „rekatolizace“ archeologicky pohřební výbava není doložena, nevypovídá nic o její prrítomnosti či nepř́ítomnosti v době samotného pohřebního aktu. Pouze malá část pohřební výbavy totiž byla $\mathrm{v}$ tomto období vyrobena $\mathrm{z}$ kovu, skla, kostí či jiných trvanlivých materiálů. Převážná většina běžných devocionálií tohoto období měla organický charakter. Nejčastěji se používalo dřevo, papír, kủže, textil, ale např́íklad i vosk, nepálená hlína či semena. Pokud hrobová výbava neobsahovala části z trvanlivých materiálů, v terénu po ní stopy většinou nezaznamenáme.

Uvedená fáze končí jednak vydáním tolerančního patentu, jednak sérií restriktivních nař́zení v oblasti pohřebnictví, vydaných za vlády Josefa II. v letech $1781-1784{ }^{6}{ }^{6}$ Ta se výrazně promítla jak do samotného pohřebního ritu, tak do stratigrafie pohřebišt'. Způsob pohřbívání patrně nejvíce ovlivnila dvojice dvorních dekretů (ze dne 23. 8. a 13. 9. 1784), které nařizovaly, aby každá farnost měla pouze jedinou obecní rakev, v níž se budou mrtvoly dopravovat na hřbitov, dále aby nebožtíci nebyli oblečeni do šatů, pouze zašiti do režného plátna, na hřbitově byli z obecní rakve vyňati a do hrobu uloženi bez další pohřební výbavy. Přestože byla část nařízení o pohřbech v pytlích a za pomoci společné rakve pro obecný odpor obyvatelstva poměrně brzy

\footnotetext{
2 Rituál smrtelné postele a pohřeb byl v katolickém prostředí pevně vymezeným obřadem, jehož průběh kodifikoval tridentský koncil v roce 1563 a z něj vycházející normy, vydávané římskou kurií a regionální církevní správnou. Pro české země to byla zejména ustanovení pražské synody z roku 1605, římský rituál z roku 1614, pražský rituál vydaný poprvé k roku 1642, a text ustanovení pražské synody o svátostech, který byl pro potřeby českých duchovních vydán znovu v letech 1684 a 1762 (Synodus Archi-Dioecesana Pragensis. Habita ab Illustrissimo \& Reverendissimo Domino Domino Sbigneo Berka, Dei [et] Apostol. Sedis Gratia Archi-Episcopo Pragensi, \& Principe Legato Nato, \& c. Anno a Christi Nativitate M.D.C.V. In Festo S. Wenceslai Principis Martyris Ac Patroni). Důležitým pramenem pro poznání průběhu místního pohřebního obřadu jsou dále katechismy, vydávané pražským arcibiskupstvím, ordinaria místních řádových domů, normativní př́íučky typu „Ars Moriendi““ a v neposlední řadě testamenty zemřelých. V 18. století se průběh pohřebního ritu řídil rovněž právními normami státní provenience (zákony Marie Terezie a Josefa II.).

3 Problematiku archeologicky zkoumaných židovských pohřebišt' otevřel F. Adámek v bakalářské práci obhájené na Katedře archeologie FF Univerzity Hradec Králové „K odrazu židovského osídlení v archeologických pramenech na území ČR“ (Adámek 2012). Pro židovský pohřební ritus je typické, že mladší hroby nesmí narušit starší, ústa a oči zemřelého bývaly zakrývány kameny nebo úlomky keramiky a rakve mohly být opatřeny visacími zámky (Unger 2002a, 46).

4 V letech 2006 až 2008 bylo u Solnice na Rychnovsku pracovníky Muzea Orlických hor v Rychnově nad Kněžnou archeologicky prozkoumáno pohřebiště českých bratř́í. Lokalita je s velkou mírou pravděpodobnosti datována kšaftem Jiříka Sladovníka z roku 1533, jímž přenechal svou zahradu českým bratř́m na pohřebiště, přičemž poslední pohřeb zde proběhl v roce 1610 (Beková 2007, 283). V rámci výzkumu byly zdokumentovány pozůstatky pravděpodobně 217 jedinců. Zemřelí byli pochováni zpravidla pouze v tkaných rubáších a jen výjimečně v rakvích. Oproti katolickým pohřbům tyto hroby takřka neobsahovaly dalši pohřební výbavu. Výzkum je významný jednoznačným časovým ohraničením a náboženskou prŕslušností zemřelých, zatím nebyl publikován v odborném tisku.

5 Mezi první takové patrně náleží hřbitov u Invalidovny v Praze-Karlíně, založený v 80 . letech 18. století, odkrytý v rámci archeologicko-antropologického výzkumu v Pernerově a Korybutově ulici v roce 2013.

6 Konkrétně šlo především o dvorní dekret ze dne 23. 8. 1781 č. 2951, který ustanovil uzavření všech hřbitovů nacházejících se uvnitř osad, a nařídil jejich zřizování v náležité vzdálenosti od osady (Svatoš 1928, 45), a rezoluci Josefa II., jíž se zakazovalo pohřbívání v kostelech a hrobkách, vydanou 21. 3. 1782 (Kryštůfek 1898, 205). V roce 1784 pak vychází dvorní dekret (ze dne 20. 8. 1784), který opět nařizoval uzavření všech hrobek, hřbitovů a božích polí v intravilánech obcí a jejich přeložení na odlehlá místa. Uzavřeny měly být rovněž hrobky v klášterech a takzvané šachty a vápenné jámy ve špitálech, u milosrdných a alžbětinek.
} 


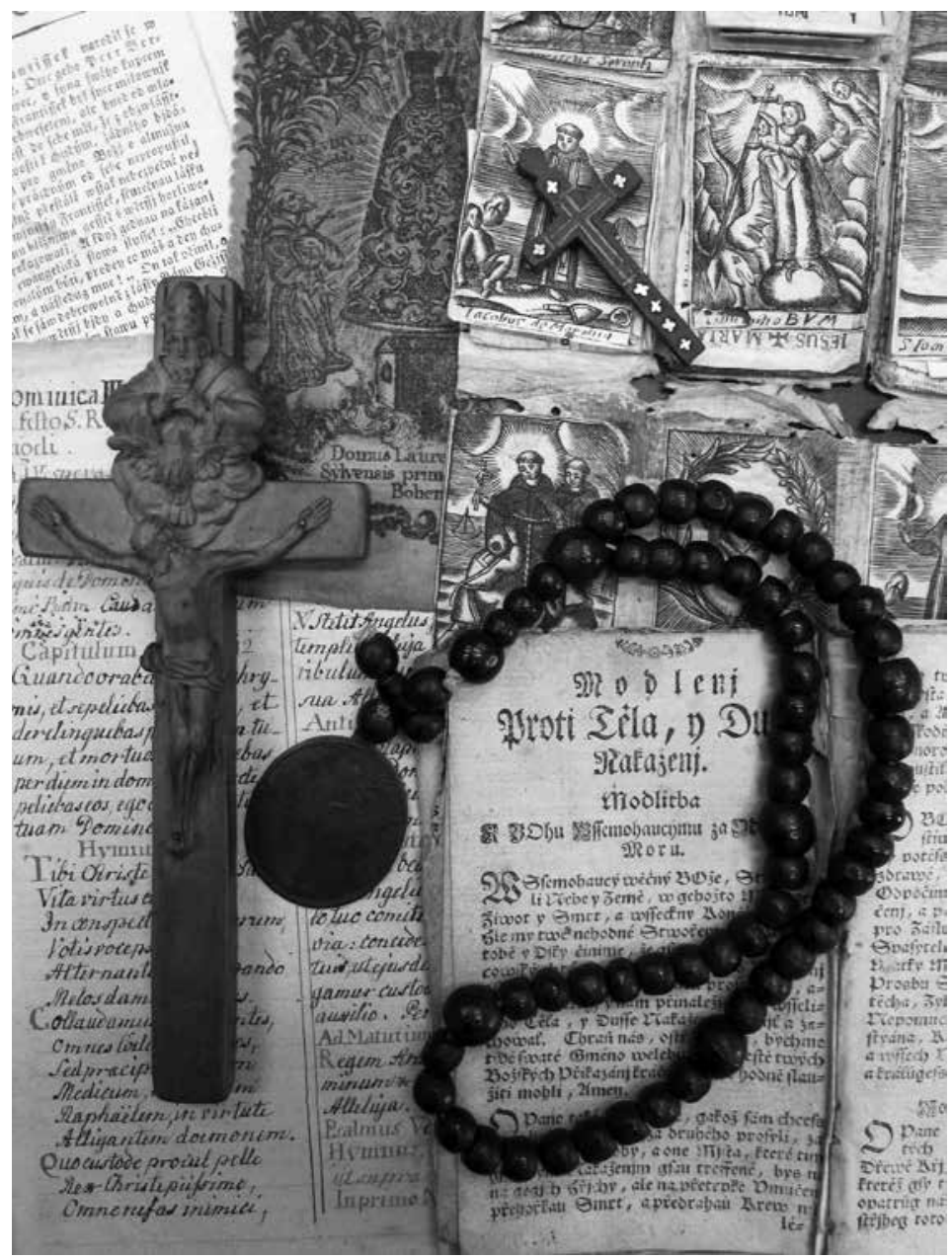

Obr. 1. Dřevěný křiž do ruky, dřevěný růženec spojený konopným provázkem s kovovým medailonem s vyobrazením sv. Benedikta, dřevěný závěsek v podobě jeruzalémského kříže, ochranný tisk s loretánskou madonou na hedvábí, devítkový škapulír ze skládaného papíru, další náboženské tisky a rukopis na papíru. Funkěně mohly být všechny tyto předměty vloženy do jediného hrobu, archeolog by ale přesto s vysokou mírou pravděpodobnosti během výzkumu zachytil pouze jediný - kovový medailon. Zbytek by v půdě postupně podlehl rozkladu. Nepublikováno. Zdroj srovnávací sbírka autorů, 18. století.

Abb. 1. Handkreuz aus Holz, Rosenkranz aus Holz durch Hanfschnur mit einem Medaillon aus Metall verbunden, das den hl. Benediktus zeigt, Anhänger aus Holz in Form eines Jerusalemer Kreuzes, Schutzdruck mit lauretanischer Madonna auf Seide, Breverl aus gefaltetem Papier, weitere religiöse Drucke und Handschriften auf Papier. All diese Gegenstände hätten funktionell einem Grab beigegeben können sein, ein Archäologe würde trotzdem bei einer Grabung höchstwahrscheinlich nur einen davon - das Medaillon aus Metall - vorfinden. Der Rest wäre nach und nach in der Erde verwest. Quelle Vergleichssammlung der Verfasser, 18. Jahrhundert.

odvolána, z hlediska archeologie nejdůležitější body josefínské pohřební reglementace zůstaly i nadále $\mathrm{v}$ platnosti. Jednalo se o ty části nařízení, které zakazovaly pohřby $\mathrm{v}$ intravilánech sídelních aglomerací, a to včetně pohřbů do krypt pod kostely. V důsledku toho dnes mohou archeologové poměrně oprávněně předpokládat, že pokud zkoumají zaniklý hřbitovní areál uvnitř historické části městské aglomerace, je velice málo pravděpodobné, že se zde setkají s pohřby 
uloženými do země po roce 1785 . Navzdory vyslovenému je i zde nutná opatrnost. Hlavně ve vesnickém prostředí se rušení hřbitovů v intravilánech obcí mnohdy posouvá až do 19. století.

Třetí fáze začíná zhruba rokem 1785. Charakteristické je pro ni obnovování, popřípadě nové zakládání protestantských pohřebních okrsků, a postupná, nicméně výrazná změna formální podoby předmětů pohřební výbavy ovlivněná všeobecným technologickým pokrokem. Koncem 18. století se uzavřelo období relativně pomalého technického vývoje starého kontinentu a nastupující strojní výroba $\mathrm{v}$ rámci průmyslové revoluce záhy vytlačila tradiční dílenskou výrobu. Zatímco pro období do 80 . let 18 . století je typická dílenská výroba s výraznými stopami ruční práce, pro následující období je již častěji charakteristická strojní výroba převážně s dokonalým, strojovým, provedením jednotlivých výrobků a je jedno, zda jde o předměty duchovní nebo světské povahy. Od počátku 19. století rovněž výrobci ustupují od umistování latinských nápisových zkratek na svátostky, jak tomu běžně bylo v předchozím období, ve prospěch národních jazyků. Němčina přitom u devocionálií v první polovině 19. století na našem území převládala. V českém prostředí sice dosud publikovaného archeologického materiálu pro 19. století, na kterém by šlo vyřčené doložit, není mnoho, tuto mezeru si ale můžeme doplnit komparací publikovaného materiálu sbírkového charakteru z Čech (Přibil 1938), z Rakouska (Keller 2008 a 2010) či Německa (Fassbinder 2003; Melisch-Escher-Jungklaus 2011). Prozatím nejpř́inosnější pro toto období je studie popisující výzkum hřbitova u kostela sv. Klimenta v Praze-Bubnech (Kostka-Šmolíková 1998). Publikace dostatečného množství dat pro pohřební ritus 19. století je ale v Čechách jen otázkou času. Vždyt' pouze několik kilometrů od kostela sv. Klimenta proběhl na české, ale i evropské poměry rozsáhlý výzkum části hřbitova u Invalidovny v Praze-Karlíně spadajícího převážně do 19. století a čítajícího zhruba 1500 anatomicky uložených jedinců.

Přibližně od poloviny 19. století navíc devocionálie ztrácí pro dataci hrobových kontextů své do té doby takřka výhradní postavení a jsou mnohdy nahrazeny kvalitním datačním materiálem světského charakteru. Ke zkoumaným pohřebním areálům v tomto období patří často hroby spojené s válečnými konflikty, které se odehrávaly na našem území. Pro 19. století jsou to hlavně hroby padlých v prusko-rakouské válce, pro období 20 . století hroby spojené s poslední fází druhé světové války. V obou případech se jedná o hroby jak vojáků, tak i civilních obětí z obou stran konfliktu?

U navrženého časového členění vychází výše uvedený text $\mathrm{z}$ historických mezníků z toho důvodu, že tato data sice na první pohled ohraničují pouze změny historické, ty se ale výrazně odráží v hrobových výbavách (nikoli v samotném způsobu uložení těl) následně dokumentovaných archeologickými prostředky. Přesto toto dělení nemá za cíl bourat či měnit zaběhlou archeologickou dataci novověku. Není k tomu důvod. Pouze se snaží pro dílčí segment novověké archeologie (novověký pohřební ritus) na obecném historickém pozadí představit logické užší - časové celky, v terénních situacích často rozlišitelné.

\footnotetext{
7 Prozatím nejmladší pohřeb cíleně vyzvednutý akreditovaným archeologickým pracovištěm (výzkum číslo 2014/38 Národního památkového ústavu, územního odborného pracoviště v hlavním městě Praze) je výzkum ostatkủ kněze Josefa Toufara, který byl pohřben v hromadném hrobě v pražských Ďáblicích. Josef Toufar vedl farnost ve vysočinské obci Číhošt', kde v roce 1949 došlo k tzv. číhošt'skému zázraku; o třetí adventní neděli se na oltáři kostela pohnul dřevěný křiž. Následně faráře Toufara zatklo StB a Toufar po sérii výslechủ 25 . února 1950 zemřel na klinice v Legerově ulici a v hromadném hrobě v pražských Ďáblicích byl uložen pod jménem Josef Zoukal. Necíleně byl při této akci ale vyzvednut ještě další kosterní materiál, který se nacházel nad Toufarovými ostatky, a před odkrytím Toufarovy kostry musel být vyzvednut také. Právě tato skutečnost, narušení mladších hrobů uložených nad knězem Toufarem, vyvolala ve sdělovacích prostředcích poměrně rozsáhlou polemiku. Zprávy iDNES - V Praze odkryli masový hrob. Skrývá kosti umučeného kněze Toufara?, http://zpravy.idnes.cz/toufar-hrbitov-ostatky-0s0-/domaci.aspx?c=A141108_142425_domaci_hv, cit. 9. 1. 2017. Ta, obdobně jako polemika při vyzvedávání pohřbů německých obětí divokých odsunů po druhé světové válce, ukázala, jak mizivá hranice je v některých případech mezi historickou vědou a politikou. Zprávy iDNES - Němec žádá Dobronín o pomník obětem války. Obec chystá hlasování, http://jihlava.idnes.cz/nemec-zada-dobronin-o-pomnik-obetem-valky-obec-chysta-hlasovani-pv8-/jihlava-zpravy.aspx?c=A101206_153928_jihlava-zpravy_dmk, cit. 9. 1. 2017. S obdobnými polemikami je nutné počítat u těchto typů výzkumů i nadále.
} 


\section{Bádání novověkého pohřebního ritu v Čechách v letech 2000 až 2016}

\section{Trocha statistiky nikoho nezabije...}

V roce 2010 otiskla Archaeologia historica konferenční prríspěvek Martina Čechury (2010, 111-120), ve kterém autor mimo jiné prezentoval na základě informací ze systému Archeologické databáze Čech (databáze Archiv ARÚ AV ČR, Praha, v. v. i.) statistický výčet výzkumů vrcholně středověkých a novověkých pohřebních okrsků pro rozmezí let 1990 až 2006 . Z uvedených dat vyplývá, že v období mezi roky 1990 až 2006 bylo v Čechách realizováno 533 výzkumů daného typu (tj. 32,5 výzkumů tohoto typu ročně), přičemž pouze u zhruba $16 \% \mathrm{z}$ nich bylo zachyceno více než 15 hrobů. Za prŕćčinu tak nízkého počtu odkrytých hrobů lze považovat skutečnost, že většinu provedených archeologických výzkumů tvořily drobné záchranné akce jako výkopy pro kanalizaci nebo drenážní rýhy pro odvzdušnění zdiva, vyvolané rekonstrukcemi kostelů (Čechura 2010,112). Největší archeologický boom v této oblasti bylo možné vysledovat v letech 2001 až 2004, kdy v naposled uvedeném roce stoupl počet sledovaných akcí na číslo 46.

Ze stejného zdroje byla pro potřeby této studie zpracována data pro období od roku 2000 do začátku roku 2013 (graf 1). Tentokrát pouze se zaměřením na takové pohřební areály, $v$ nichž se jednoznačně podařilo identifikovat novověké pohřby bez ohledu na to, zda byly prrítomny i starší, středověké. Lokality se středověkými pohřby (bez novověkých) do statistiky zahrnuty nebyly.

Celkově tedy bylo na území Čech v letech 2000-2013 provedeno 252 archeologických akcí, které (datované od konce 15 . do 1 . poloviny 20 . století) zachytily novověké lokality s potvrzenou prŕtomností pohřbu nebo pohřbů. (Do statistiky byly zahrnuty i lokality, na kterých se sice hroby nacházely, ale archeologickým výzkumem narušeny nebyly, tedy lokality, kde výzkum zachytil novověké pohřby pouze $\mathrm{v}$ druhotných polohách, nebo se výzkum pohyboval ve zkoumaném areálu nad úrovní těchto hrobů, nebo v bezprostřední blízkosti těchto hrobů; počet archeologických akcí, které skutečně novověký pohřeb nebo pohřby zachytily, činil 193.) Z generovaných dat dále vyplývá, že stejně jako u statistického výstupu M. Čechury bylo i pro novověké horizonty prvních pět let po roce 2000 na výzkumy nadprůměrně bohatým obdobím. Tuto skutečnost lze připsat tehdy vrcholícímu stavebnímu boomu. Po roce 2000 se v průměru realizovalo ročně 19 výzkumů řešících mimo jiné i novověké pohřební lokality. Z tohoto počtu výzkumů se u pouze

Přehled archeologických akcí, při kterých došlo k zachycení novověkého pohřbu/ pohřebního okrsku,

na území Čech v letech 2000-2013

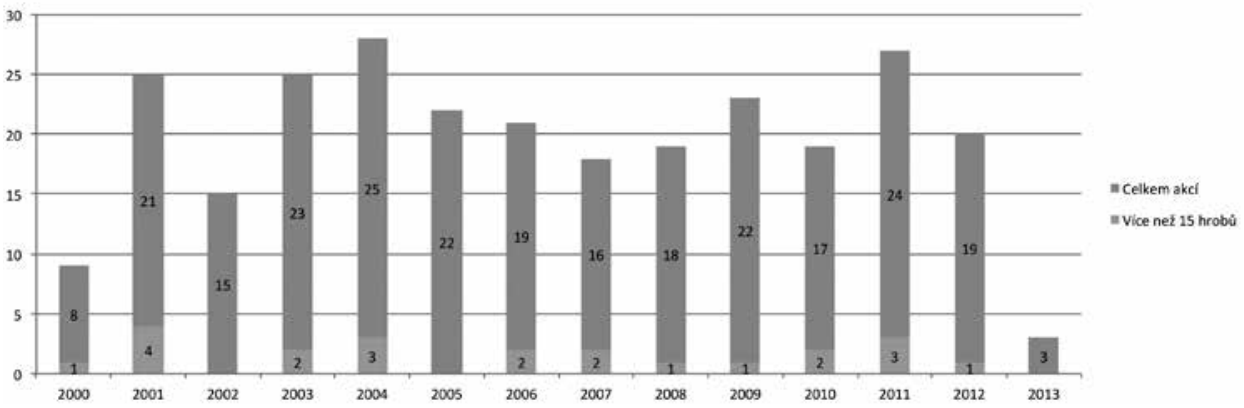

Graf 1. Přehled archeologických akcí provedených v Čechách v letech 2000-2013, zachycující lokality s potvrzeným pohřbem nebo pohřby datovanými do období konce 15. až 1. poloviny 20. století. Zdroj dat Archiv ARÚ AV ČR, Praha, v. v. i., Archeologická databáze Čech, verze 3.1 (2013).

Diagramm 1. Übersicht der in den Jahren 2000-2013 in Böhmen durchgeführten archäologischen Grabungen, bei denen Fundstellen bestätigter Bestattung oder Bestattungen aus der Zeit zwischen Ende 15. bis zur ersten Hälfte des 20. Jahrhunderts erfasst wurden. Datenquelle Archiv des Archäologischen Instituts der Akademie der Wissenschaften der Tschechischen Republik, Prag, öffentliche Forschungseinrichtung, Archäologische Datenbank Böhmens, Version 3.1 (2013). 
Přehled archeologických akcí, při kterých došlo k zachycení novověkých pohřbů/ pohřebních okrsků,

na území Čech v letech 2000-2013 podle typu prostředí

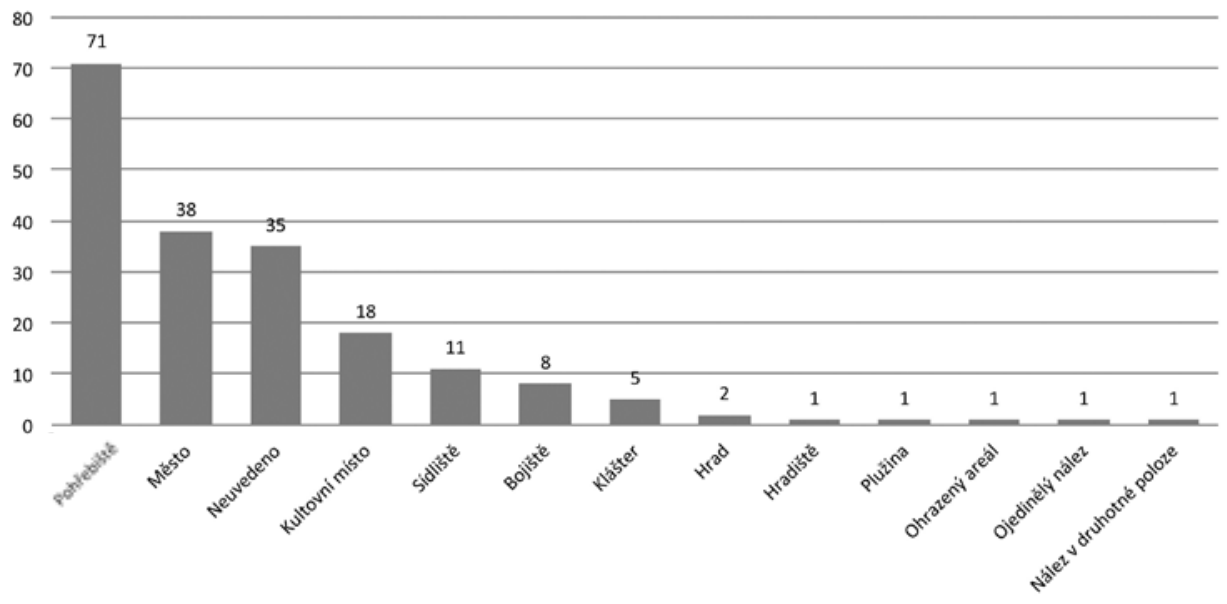

Graf 2. Typová specifikace areálů dle Archeologické databáze Čech s dokumentovanými novověkými pohřby z rozmezí let 2000-2013. Zdroj dat Archiv ARÚ AV ČR, Praha, v. v. i., Archeologická databáze Čech, verze 3.1 (2013).

Diagramm 2. Typenspezifikation der Areale gemäß der Archäologischen Datenbank Böhmens mit in der Zeit zwischen 2000-2013 dokumentierten neuzeitlichen Bestattungen. Datenquelle Archiv des Archäologischen Instituts der Akademie der Wissenschaften der Tschechischen Republik, Prag, öffentliche Forschungseinrichtung, Archäologische Datenbank Böhmens, Version 3.1 (2013).

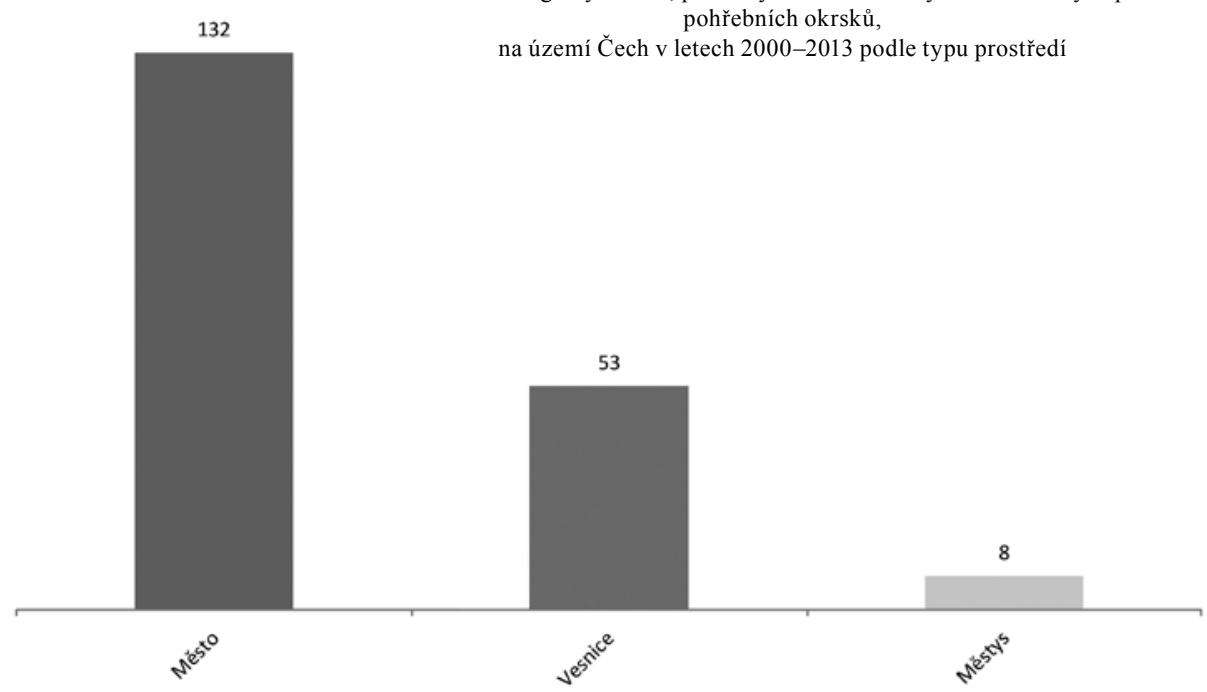

Graf 3. Současná příslušnost zkoumaných areálů k jednotlivým typům katastrálního členění urbanistických celků, na jejichž území byly v rozmezí let 2000-2013 dokumentovány novověké pohřby. Zdroj dat Archiv ARÚ AV ČR, Praha, v. v. i., Archeologická databáze Čech, verze 3.1 (2013).

Diagramm 3. Gegenwärtige Zugehörigkeit der untersuchten Areale zu den jeweiligen Typen der katastralen Gliederung urbaner Komplexe, auf deren Gebiet in der Zeit von 2000-2013 neuzeitliche Bestattungen dokumentiert wurden. Datenquelle Archiv des Archäologischen Instituts der Akademie der Wissenschaften der Tschechischen Republik, Prag, öffentliche Forschungseinrichtung, Archäologische Datenbank Böhmens, Version 3.1 (2013). 
asi $12 \%$ podařilo zachytit více než 15 hrobů. Šlo tedy opět z převážné většiny jen o drobné akce, zasahující úzce vymezenou plochu.

Co do dobové typové specifikace areálů s dokumentovanými novověkými pohřby nejvíce ve sledovaném období dohledáme areály pohřebišt', následují města a lokality blíže nespecifikované. Ve výčtu se objevují také kultovní místa, sídliště, bojiště, kláštery, hrady, hradiště, plužina či ohrazený areál. Ale i ojedinělý nález či nález v druhotné poloze. Přesný výčet jednotlivých údajů je uveden v připojeném grafu (graf 2).

Pokud se zaměříme na příslušnost zkoumaných areálů $\mathrm{k}$ jednotlivým typům současného katastrálního členění urbanistických celků, na jejichž území byly v rozmezí sledovaných let dokumentovány novověké pohřby, zjistíme výrazné zastoupení akcí spojených s městským prostředím na úkor vesnic a městysů (graf 3 ).

\section{Publikovaná pramenná základna}

Přes uvedená omezení přineslo častější vyzvedávání novověkých hrobů a jejich inventářů v oblasti bádání novověkého pohřebního ritu několik pozitivních změn. Především jednotlivá odborná pracoviště začala ve větši míře chápat novověké pohřební horizonty z archeologického hlediska za hodné dokumentace. Dalším efektem byl postupný nárůst publikovaných titulů $\mathrm{k}$ dané problematice vyvolaný potřebou zpracovávat vyzvednutý materiál. Šlo zejména o dílčí přehledy provedených výzkumů a shrnutí dosavadního stavu poznání (Unger 2002; 2006; Blažková-Dubská 2005, 201-216; Krajíc 2007, 57-96; Králíková 2007; Čechura 2010, 111-120;

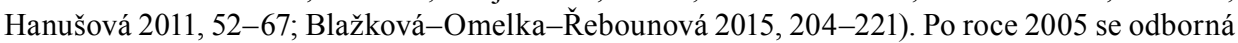
literatura dále rozrůstala o studie zaměřené na rozbor nálezových souborů a komplexní zpracování jednotlivých lokalit.

Prozatím nejpř́nosnější lokalitou k poznání postmedieválního katolického pohřebního ritu v městském prostředí zůstává pro Čechy archeologický výzkum zaniklého hřbitova při kostele sv. Jana Křtitele v Oboře ve Šporkově ulici čp. 332/III na Malé Straně v Praze. Lokalita s 906 zdokumentovanými anatomicky uloženými pohřby byla v terénu zkoumána v roce 2002, kdy bylo vyzvednuto 639 pohřbů, a v roce 2004, kdy bylo vyzvednuto dalších 267. Od roku 2004 probíhá zpracování výzkumu soustředěné nejen na základní, popisné konstatování stavu nálezové situace, ale hlavně na co nejlepší pochopení pohřebního ritu v dobovém kontextu. Vzhledem ke svému rozsahu je výzkum prezentován odborné veřejnosti průběžně, po logických celcích, a jeho základním pilířem je vedle odborného interdisciplinárního zpracování archeologických nálezů i výzkum písemného materiálu z archivních fondů, dobové literatury a archeologických nálezů vzešlých z jiných archeologicky zkoumaných lokalit.

Výzkum tak postupně přináší cenné údaje zejména pro poznání pohřebního ritu a pohřební výbavy různých sociálních skupin barokního měštanstva, včetně upřesnění datace jednotlivých pohřbů a dalších aspektů dobových zvyklostí a zbožnosti (např. činnosti náboženských bratrstev, lidové pověrčivosti, fenoménu poutí) a pomáhá určovat způsob bádání i pro další místa v Čechách.

Vedle základních informačních textů uveřejněných v rámci výročních zpráv NPÚ (Omelka 2003, 100-106; 2006a, 77-78) a katalogu z výstavy „Pražská pohřebiště a hřbitovy“ (Laštovková 2006, 95-98; Omelka 2006, 90-94) se zde od počátku věnovala vysoká pozornost zpracování pohřební výbavy. Vznikla série článků řešících postupně jednotlivé materiálové skupiny nálezů: prsteny (Omelka-Šlancarová 2007, 671-709), korálky (Omelka-Řebounová 2008, 605-679), odpustkové křižze a křižové závěsky obecných forem (Omelka-Řebounová-Šlancarová 2009, 1001-1083), speciální kříže (Omelka-Řebounová-Šlancarová 2010, 423-476), špendlíky (Omelka-̌̌ebounová-Šlancarová 2011, 523-540), medailky (Omelka 2006b, 144-152; Omelka- ̌̌ebounová 2012, 983-1019; 2016, 309-325). Současně byly publikovány studie věnované materiálovému složení vybraných kovových nálezů (Frána-Fikrle 2007, 711-716; 2009, 1085-1093), historickému vývoji lokality (Omelka 2009, 93-101), sociální a demografické struktuře pohřebiště z pohledu antropologie a písemných pramenů (Omelka-̌̌ebounová 2012a, 233-250) nebo 


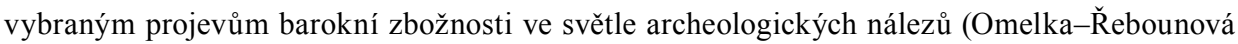
2011, 268-298; 2014, 243-268).

Z dalších pražských výzkumů si pozornost zaslouží záchranný archeologický výzkum v prostoru kasáren Jiř́ího z Poděbrad na náměstí Republiky v Praze, realizovaný v roce 2004, při kterém byl mimo jiné zkoumán hřbitov kapucínského kláštera u Sv. Josefa (Juřina a kol. 2007;

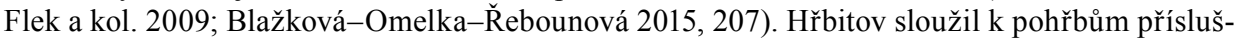
níků klášterní komunity. Při výzkumu byly zachyceny dvě stratigrafické úrovně hrobů s celkem 18 hrobovými celky, náležejícími dospělým mužům. V devíti hrobech byly nalezeny předměty pocházející převážně z pohřební výbavy. U všech 18 skeletů byla provedena antropologická analýza, při které se v několika prŕípadech podařilo diagnostikovat i některá onemocnění. Relativní chronologii existence hřbitova vymezila doba existence kapucínského kláštera v letech 1633-1795 (Flek a kol. 2009a; Blažková-Omelka-Ǩebounová 2015, 207). ${ }^{8}$ V letech 2009-2011 probíhala rozsáhlá rekonstrukce vodovodu mezi ulicemi Národní, Spálenou a Myslíkovou. Během této akce byl proveden archeologický výzkum v trase vodovodu ve východní polovině ulice V Jircháŕích (mezi Opatovickou a Voršilskou). Během bagrování rýhy pro vodovod v srpnu 2011 byla zachycena část zaniklého hřbitova při kostele sv. Michala. Prozkoumáno zde bylo 22 barokních hrobů, poslední fáze pohřbívání byla datována do druhé poloviny 18. století (OmelkaSelmi Wallisová 2012). Po roce 2000 byly rovněž publikovány některé starší výzkumy I. Borkovského. Konkrétně výzkum pohřebiště u Jízdárny (výzkum z let 1951-1952), datovaného na základě archeologických a písemných pramenů rámcově do období kolem poloviny 17. století a odhalujícího patrně pohřby vojáků švédské armády, kteří se účastnili obléhání Prahy v roce 1648 (Blažková-Dubská 2005a; 2006). V roce 2011 pak výsledky výzkumu pohřebiště na Loretánském náměstí na Hradčanech, realizovaného I. Borkovským ve 30 . letech 20. století. Plocha zdejšího hřbitova byla s minimálně dvěma přerušeními využívána od raného středověku až do raného novověku (polovina 11. až polovina 16. století). $Z$ nejmladší fáze pohřebiště jsou doloženy nálezy dekapitovaných jedinců, včetně vícečetných pohřbů (Boháčová-Blažková 2011; Blažková-Omelka-̌̌ebounová 2015, 209).

Zaniklý plzeňský pohřební areál u bývalého špitálního kostela sv. Máří Magdalény vydal při archeologickém výzkumu v letech 2010 až 2014 celkem 219 v novověku pohřbených jedinců uložených v anatomické poloze. Na rozdíl od Šporkovy ulice se zde autorům výzkumu podařilo publikovat výsledky bádání v ucelené kolektivní monografii (Dudková-Orna 2015) shrnující poznatky o historii lokality a hřbitova, antropologickou analýzu vyzvednutých jedinců a rozbor části vyzvednutých nálezů. ${ }^{9}$ Mimo tuto řadu vydala Západočeská univerzita v Plzni v roce 2015 samostatně kompletní katalog zde vyzdviženého kosterního materiálu (Galeta a kol. 2015).

\section{Studium hmotných projevi̊ pohřebního ritu na základě dosavadních publikačních výstupi̊}

Pokud se chceme seznámit se stavem bádání hmotných projevů novověkého pohřebního ritu v Čechách v našem tisíciletí, nemůžeme začít jinak než studií Bedřicha Přibila popisující československé medaile a svátostky s obrazem svatého Václava, publikovanou v roce 2006 (Přibil 2006, 39-51). Studie vydaná v almanachu Posel z Budče totiž charakterizuje stav našeho bádání $\mathrm{v}$ dané problematice na počátku třetího tisíciletí. Na tom by nebylo nic neobvyklého, pokud by předmětný článek nebyl otištěn se zhruba sedmdesátiletým odstupem od jeho sepsání. Jedná se totiž o jednu ze studií připravovanou pro sborník oslavující svatováclavské milénium v roce 1929, za první republiky ovšem nevydaný. To, že studie zůstala i po více než sedmdesátileté

\footnotetext{
8 Pro přehled uvádíme, že několik málo nálezů získaných z raně novověkého až novověkého pohřebního kontextu z klášterního prostředí bylo publikováno v rámci monografie o Kladrubském klášteře (Nováček 2010, 78) a Anežském klášteře v Praze (Soukupová 2011, 295-297).

9 V historické části se zde můžeme seznámit s historií špitálního areálu (Dudková-Orna-Netolický 2015, 9-23), historií špitálního kostela sv. Máŕi Magdalény a jeho pohřebního okrsku (Dudková-Orna 2015a, 24-31; 2015a, 40-43) a demografickou a sociální strukturou pohřbů na základě písemných pramenů (Řebounová 2015,32-39). Antropologická část čtenár̆ům přibližuje základní antropologické zhodnocení (Galeta a kol. 2015a, 46-53), předkládá případové studie (Šneberger a kol. 2015, 54-67) a ukázku způsobu rekonstrukce podoby jedince podle lebky (Zedníková-Malá 2015, 68-75). Č́st zabývající se hmotnou kulturou tvoří studie řešící rozbor hrobových nálezů duchovní povahy (OmelkaŘebounová 2015, 78-99), katalog náboženských medailek (Omelka-Řebounová 2015a, 100-110) a katalog křižů (Omelka-Řebounová 2015b, 112-122). V poslední části publikace pak můžeme najít zajímavou studii věnovanou uplatňování památkové péče na lokalitě (Waldmannová 2015, 131-133).
} 
pauze stále v publikovatelném stavu, je dokladem naprosto okrajového zájmu vědecké komunity o danou problematiku v druhé polovině dvacátého století, a tím pádem i velice malého posunu našeho poznání v ní.

Teprve výše zmíněná série výzkumů po roce 2000 řešící, mimo jiné, novověká pohřebiště oživila alespoň částečně zájem o dané téma a následně se tak, byt' velmi zlehka, opět začala posouvat hranice znalostí.

Vedle Šporkovy ulice (viz výše) se pohřební výbavě v Praze ve sledovaném období věnují dvě studie řešící nálezy z novověkého hřbitova na samém východním okraji areálu bývalých kasáren Jiřího z Poděbrad (Flek a kol. 2009, 107-109; 2009a, 407-452) a okrajově i studie řešící nové nálezy v areálu bývalého hřbitova u kostela sv. Jindřicha na Novém Městě pražském (Omelka-Starec 2002, 141-154).

Vedle pražských lokalit byla problematika devocionálií zkoumána i na základě nálezů ze hřbitova u kostela sv. Bartoloměje v Rakovníku (Čiháčková-Omelka-̌̌ebounová 2011, 10291049), nálezů z výzkumu při kostele sv. Mikuláše v Českých Budějovicích (Hanušová-Thomová 2012, 209-229), dále nálezů ze souboru výzkumů na Liberecku (Brestovanský 2012, 123-134), ze studia „depotu“ kovových plastik ukřižovaného Krista z Hut'ského rybníka v Dobř́íši (Korený-Omelka-Řebounová 2012, 260-277), z výzkumu hrobových nálezů z kostela sv. Jana Křtitele v Jindřichově Hradci (Omelka-Řebounová-Čechura 2013, 379-395), pohřební výbavy Bohunky Lobkovické ze Šternberka (Pilná-Schmollová 2014, 155-169) či nálezů z plzeňské lokality U Zvonu (Omelka-̌̌ebounová 2015, 78-99; 2015a, 100-110; 2015b, 112-122). Do výčtu náleží i studie řešící ojedinělý nález dvojice Benediktových křižků z Hradební ulice v Chrudimi (Frolík a kol. 2010, 193-208).

\section{Výsledky dosavadního stavu bádání a nástin perspektiv}

Pokusíme-li se o shrnutí, můžeme se zatím v úvahách o typických projevech novověkého pohřebního ritu v Čechách opřít pouze o několik málo lokalit, ze kterých jednak pochází dostatečné množství nálezového materiálu a jednak jsou natolik dobře zpracovány, aby je bylo možno považovat za reprezentativní vzorky se širší vypovídací hodnotou. Jedná se převážně o výzkumy, u kterých byla většina nálezů datována do závěru 17. až druhé poloviny 18 . století. Jde o pozůstatky pohřebních výbav náležících městskému obyvatelstvu katolického vyznání (viz výzkumy pražské Šporkovy ulice, plzeňské lokality U Zvonu, hřbitovů při rakovnickém kostele sv. Bartoloměje a jindřichohradeckém kostele sv. Jana Křtitele).

Při zamyšlení se nad důvodem tohoto časového zúžení dojdeme k závěru, že zde pracujeme s ostatky uloženými do země převážně až na sklonku pohřbívání na daných lokalitách, ale že na druhé straně tyto situace nepředstavují závěrečné horizonty pohřbívání na těchto hřbitovech. Nejmladší hřbitovní úrovně, do kterých patřily ještě nezetlelé pohřby, byly na základě nařízení Josefa II. z uvedených hřbitovů v převážné většině odstraněny (odvezeny). U etážových hřbitovů, které jsou v baroku běžné, pak byly starší pohřby velice často likvidovány mladšími, a to při postupné rotaci pohřbů na jednotlivých pohřebních místech. To vede jednak k naprosté ztrátě přehlednosti a asociačních vztahů mezi uloženými pohřby, jednak ke zkreslení původního reálného vytížení pohřebního okrsku. Ve Šporkově ulici bylo například na základě záznamů z matrik doloženo, že 906 anatomicky uložených jedinců odkrytých zde při archeologickém výzkumu odpovídá počtu pohřbů vypravených na této lokalitě během pouhého jednoho desetiletí (Omelka-̌̌ebounová 2012, 249).

Jak již bylo uvedeno výše, pro období 19. století, ale v podstatě ani pro období 16. století, v současnosti nemáme př́liš publikovaného archeologického materiálu a tuto mezeru je zatím 
třeba kompenzovat materiálem sbírkového charakteru nebo výsledky archeologických výzkumů ze zahraničí. ${ }^{10}$

Pro období 16. století lze za doposud nejreprezentativnější vzorek pro území Čech považovat pouze pohřebiště českých bratří u Solnice na Rychnovsku, datované na základě dobových písemných pramenů mezi roky 1533 až 1610 (Beková 2007, 283), na němž byli zemřelí ukládáni do hrobů zpravidla pouze $\mathrm{v}$ tkaných rubáších a jen výjimečně v rakvích. To ostatně v předmětném období platilo většinově jak pro protestanty, tak pro katolíky (oproti pozdějším katolickým pohřbům hroby $\mathrm{z}$ tohoto období takřka neobsahují další pohřební výbavu, a jsou proto pro archeology časově obtížně uchopitelné).

Pro období 19. století je na území Čech důležitý publikovaný výstup z výzkumu hřbitova u kostela sv. Klimenta v Praze-Bubnech (Kostka-Šmolíková 1998), na jehož nálezovém souboru lze dobře sledovat proměnu formy pohřební výbavy, a podstatné poznatky očekáváme také od analýzy nálezů a situací z odkryvu hřbitova u Invalidovny v Praze-Karlíně. Po zpracování této lokality nastane ideální př́ležitost provést př́ípadnou korekci dosavadních představ a úsudků.

Dále můžeme konstatovat, že se stav poznání novověkých pohřebních areálů v Čechách od vydání př́íspěvku M. Čechury (2010, 111-120), kterým bilancoval stav bádání pohřebního ritu ve středověku a novověku od jeho počátků v 19. století do roku 2006, resp. 2010, mírně posunul $\mathrm{k}$ lepšímu, a to zejména $\mathrm{v}$ oblasti výzkumu městských raně novověkých / novověkých katolických pohřebních okrsků. Stalo se tak především díky systematickému interdisciplinárnímu zpracovávání bohatého nálezového souboru ze hřbitova sv. Jana v Oboře ve Šporkově ulici v Praze a plzeňské lokality „U Zvonu“. Přestože se jednalo o záchranné archeologické výzkumy, které odkryly jen část plochy zaniklých pohřebních okrsků, zachytily značné množství osteologického materiálu i pohřební výbavy zemřelých, u nichž byla zajištěna jak podrobná antropologická analýza, tak důkladné zpracování alespoň nejvýraznějších skupin nalezených předmětů (zejména korálků, prstenů, kř́ižových závěsků a náboženských medailek). Současně zde byly $\mathrm{k}$ dispozici dobové písemné prameny (matrik, testamentů aj.), které napomohly rekonstruovat identitu zemřelých, spádovou oblast pohřbívání nebo reálnou vytíženost pohřebiště v průběhu období předpokládaného uložení nalezených jedinců do hrobu (Omelka-Řebounová 2012a, 233-250; Rebounová 2015, 32-39).

Bohužel stále platí, že širší poznání podoby a proměn pohřebního ritu v českém prostředí výrazně limituje charakter archeologických výzkumů, které z převážné většiny tvoří drobné záchranné akce (viz např. Kostrouch-Kodera 2010; Omelka-Selmi Wallisová 2012). Výzkumy větších ploch, natož systematicky a interdisciplinárně zkoumaných, zůstávají výjimkou.

Vývoj studia pohřebního ritu nadále brzdí nedostatek vydaných, kvalitně zpracovaných nálezových souborů (Čechura 2010, 114). Chybí materiálové studie věnované zevrubnému rozboru a srovnání jednotlivých kategorií předmětů z vyzvednutých hrobových inventářu - například souborů medailek, relikviářů, pohřebních korun, bratrských odznaků, šperku (náušnice) nebo oděvních doplňků (knoflíky, přezky). To následně ztěžuje publikování archeologických výzkumů a vznik syntetických srovnávacích a metodologických prací - např́íklad zaměřených

10 Pro srovnání úrovně výzkumu v Čechách a v západní Evropě doporučujeme kolektivní monografii vydanou v roce 2015 pod názvem The Archaeology of Death in Post-medieval Europe, volně vycházející ze souboru prríspěvků přednesených na konferenci pořádané Evropskou asociací archeologů v roce 2012 v Helsinkách. Monografie zaměřená na problematiku archeologie smrti v novověké Evropě poskytla prostor široké skupině badatelů $\mathrm{k}$ představení dané problematiky $\mathrm{z}$ hlediska jednotlivých evropských států a zároveň z hlediska různého přístupu k dané problematice. Vedle úvodního zastřešujícího textu od britské badatelky Sarah Tarlow (Tarlow 2015, 1-18) zde nalezneme švédskou studii řešící otázku uložení těl a materiální kultury novověkých hrobových nálezů z katedrály v Linköping (Tagesson 2015, 19-38), Angela Boyle objasňuje v průběhu doby se měnící pohledy na novověké pohřbívání v Anglii (Boyle 2015, 39-60). Francouzské bádání zastupuje studie přibližující čtenáři problematiku dopadu epidemií na pohřební praxi v novověké Francii (Souquet-Leroy-Réveillas-Castex 2015, 61-87). Lotyšsko přispělo textem obírajícím se existencí dvou způsobů pohřbívání na území dnešního Lotyšska ve 13. až 18. století (Muižnieks 2015, 88-110), Švédsku je věnován i př́íspěvek řešící tamní pohřební praxi v 16. století z hlediska pohřebního roucha (Gonzalez 2015, 111-124), Estonsku pak studie zkoumající tradice vycházející z představ o smrti, pohřbu a posmrtném životě na př́ikladu jihovýchodního Estonska (Valk 2015, 125-147). Německo zastupuje práce blízká českému prostředí, řešící tamní katolické a protestantské novověké pohřební obřady (Kenzler 2015, 148-169), dánská studie přibližuje ukládání a manipulaci s těly na moderních hřbitovech (Anthony 2015, 170-188). Finsko připojilo zajímavý text zaměřený pohřební praxi v oblasti Ostrobothnian v době od pozdního středověku do 20. století (Tranberg 2015, 189-203).

Přestože již samotné texty uveřejněné v monografii zájemce o danou problematiku pravděpodobně zaujmou, nejpřínosnější z publikovaného materiálu je v tomto př́padě takřka nepřeberný soupis aktuální evropské literatury zaměřené na problematiku novověkého pohřebního ritu. Díky širokému zastoupení badatelů z různých evropských států (bohužel se nepřipojily všechny státy) se tak kolektivní monografie může stát velice vítaným pomocníkem pro orientaci v problematice aktuálně publikovaných výstupů k novověkému pohřebnímu ritu na úrovni Evropy. 
na srovnání zvyklostí mezi regiony, různých sociálních a kulturních prostředí, pohřbů z krypt, ${ }^{11}$ tzv. nestandardních pohřbů (Čechura 2010, 117), ${ }^{12}$ pohřbů vojenských či válečných, ${ }^{13}$ porovnání dobových předpisů o nakládání s těly zemřelých s odrazem skutečné praxe v archeologických pramenech, posouzení možností datace hrobů bez výbav (např̀ na základě souvislosti s polohou horních končetin, která se ovšem, mimo jiné, dosud neprokázala), stanovení periodizace pohřebního ritu v období novověku, jak bylo naznačeno v úvodu tohoto př́spěvku, apod.; značné rezervy panují v množství publikovaných prací k problematice 19 . století. ${ }^{14}$

Velkou badatelskou výzvou zatím také zůstává výzkum sociální topografie pohřebišt'. Oproti německému prostředí, kde se od 17. století začíná u většiny hrobů projevovat pravidelný systém v uspořádání pohřebišt' (hroby respektují řady a v nich pevně dané vzdálenosti hrobů od sebe - Kenzler 2015, 155), v českém prostředí panuje jistota o pevně stanovených pravidlech pro systém uspořádání hrobů až v období Josefa II ${ }^{15} \mathrm{~S}$ danou problematikou souvisí i nedostatečné pochopení rodinných vazeb mezi hroby či místních sociálních, kulturních nebo profesních pohřebních zvyklostí. V neposlední řadě do kategorie badatelských výzev v této oblasti náleží fenomén dětských okrsků. Jejich zachycení se na zkoumaných pohřebních areálech v Čechách nesetkávalo až dosud s velkým úspěchem, především kvůli špatné uchovatelnosti dětských skeletů a v důsledku odkrývání pouhých výseků z celkové plochy pohřebišt'. Je proto otázkou, zda $\mathrm{v}$ době novověku jsou ty to okrsky ještě zakládány, popř́ípadě pro které oblasti jsou, nebo naopak nejsou typické a z jakého důvodu.

Pro pochopení sociální a demografické struktury pohřebních okrsků se jako žádoucí jeví větší zapojení historické analýzy písemných pramenů, zejména farních matrik, jak bylo provedeno např́ikad u pražského hřbitovního okrsku sv. Jana v Oboře nebo sv. Máří Magdalény

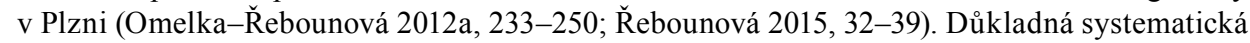
analýza církevních normativních písemných pramenů (případně též ikonografických pramenů), která stále schází, by rovněž mohla vnést více světla do otázky dobových nároků na standardní pohřeb, včetně typu oděvu, skladby pohřební výbavy nebo polohy rukou. Nezbytnou se zdá úzká spolupráce s přírodovědeckými disciplínami, především antropologií, ale též genetikou, z níž by mohl vzejít průlom v řešení výše uvedené otázky rodinných vazeb jedinců na pohřebišti (RídlSládek 2004), demografické struktury nebo sociální topografie pohřebišt'. Zde lze konstatovat, že i pro území Čech byla od roku 2000 vydána celá řada antropologických studií zaměřených na problematiku vyhodnocování kosterního materiálu z novověkých pohřebních okrsků a využívání nových metod a postupů (viz např. Sládek-Galeta-Sosna 2012; Sosna a kol. 2013). Dlouhodobě systematicky prováděný výzkum zaměřený na metody terénní antropologie a dokumentace kosterních nálezů z prostoru novověkých pohřebních okrsků, které jsou specifické velkou nepřehledností nálezových situací způsobenou etážovitým uspořádáním hrobů, představuje výzkum hřbitova u kostela sv. Ducha ve Všerubech (Průchová a kol. 2005; Sládek a kol. 2008; Galeta

11 Nadějnou se v tomto směru jeví diplomní práce na téma „Středověké a novověké krypty na území Čech, Moravy a Slovenska“, zadaná na Ústavu pro archeologii FF UK v Praze v akademickém roce 2015/2016. Zajímavé výsledky by rovněž mohlo přinést zpracování bohatého nálezového souboru získaného z krypty kostela sv. Mikuláše a sv. Alžběty v Chebu v roce 2014. Výzkum byl prezentován formou příspěvku v rámci 47. ročníku mezinárodní konference Archaeologica historica v Chebu v roce 2015 (M. Beránek-P. Hasilová-A. Shbat, Memento moripohřebiště v kryptě kostela sv. Mikuláše v Chebu).

12 Např́iklad studiem reliktů popravišt' se v českém prostředí dlouhodobě systematicky zabývá P. Sokol (viz např. Sokol 2003; 2016).

13 Této dosud téměř opomíjené problematice se věnuje například bakalářská práce M. Holase obhájená v roce 2016 na univerzitě v Hradci Králové. Autor se v ní zaměřil na zpracování sedmi dosud blíže nevyhodnocených archeologicky zkoumaných lokalit, na kterých byly zachyceny hroby vojáků padlých na Královéhradecku v prusko-rakouské válce v roce 1866 (Holas 2016). Pohřby př́islušníků armády z období 18.-19. století byly zachyceny rovněž v průběhu předstihového archeologicko-antropologického výzkumu v Praze-Karlíně, viz http://archeopro.archeo4u. cz/archeologickevyzkumy.html, cit. 9.1.2017.

14 Z publikovaných výjimek je třeba zmínit článek věnovaný archeologickému výzkumu hřbitova sv. Klimenta v Praze-Bubnech, který ovšem vyšel ještě před rokem 2000 (Kostka-Šmolíková 1998). Slibným výstupem v tomto směru by mohlo být publikování výsledků záchranného archeologického výzkumu v Poběžovicích (okr. Domažlice), v místě zaniklého špitálního hřbitova přináležejícího ke kostelu sv. Antonína z Padovy, který v roce 2010 provedlo Západočeské muzeum v Plzni (investorská zpráva č. 101/2010 Poběžovice [okres Domažlice], Mariánská ulice [Čechura]). Kromě nálezu více než 40 pohřbených jedinců byl v ploše výzkumu s největší pravděpodobností zachycen i dětský pohřební okrsek. Zdroj: Domažlický deník, http://domazlicky.denik.cz/zpravy_region/archeologove-a-antropologove20101001.html, zpráva z 3. 10. 2010, cit. 9. 1. 2017.

15 Na základě nařízení Josefa II. v rámci jeho reformy pohřebnictví mělo být tělo po smrti zašito do pytle, v obecní rakvi dopraveno na hřbitov, kde pro něj měl být vykopán hrob o hloubce 6 stop $(1,89 \mathrm{~m})$ a šiřce 4 stop $(1,26 \mathrm{~m})$. Pokud se v jeden den pohřbívalo více zemřelých, mohli být uloženi do jednoho společného hrobu. Mezi hroby bylo nařízeno dodržovat vzdálenost 4 stop. 
a kol. 2008; Píšová 2011). Z antropologických studií vyhodnocujících kosterní materiál na jednotlivých lokalitách na území Čech lze pro přehled uvést rozbor kosterních pozůstatků z kostela sv. Bartoloměje v Rakovníku (Cimbůrková 2011), rozbor kosterních pozůstatků nedospělých jedinců u kostela sv. Bartoloměje v Plzni (Průchová 2007), výše uvedené studie vzniklé z rozboru kosterního souboru ze hřbitova u kostela sv. Máří Magdalény v Plzni (Galeta a kol. 2015; 2015a; Šneberger a kol. 2015; Zedníková-Malá 2015) nebo pohřebních okrsků v Praze-Karlíně (KaclPrůchová-Rytír 2014). Zájem biologických i kulturně-sociálních antropologů se v posledních letech rovněž stáčí k problematice sekundárních pohřebních aktivit, které jsou u novověkých pohřbů běžné (Sosna 2007; Chroustovský-Průchová 2011).

A konečně vedle prohloubení mezioborové spolupráce by výzkumu novověkého pohřebního ritu v České republice v budoucnu prospěla i užší spolupráce mezi českými a moravskými odbornými pracovišti. Společné projekty na řešení dané problematiky jsou totiž prozatím spíše výjimkou. Z těch, které se již podařilo realizovat a dotáhnout k publikačnímu výstupu, je možné jmenovat spolupráci Archivuhl.m. Prahy s Muzeem Vysočiny Jihlava při rozboru nálezů šperků, devocionálií a součástí oděvů z kostela svatého Jakuba v Jihlavě (Omelka-Šlancarová 2012) nebo spolupráci na studiu novověké pohřební výbavy ze sbírky Slováckého muzea v Uherském Hradišti (Omelka- ̌̌ebounová-Menoušková 2014).

\section{Prameny a literatura}

ADÁMEK, F., 2012: K odrazu židovského osídlení v archeologických pramenech na území ČR. Bakalářská práce, Univerzita Hradec Králové.

ANTHONY, S., 2015: Hiding the Body: Ordering Space and Allowing Manipulation of Body Parts within Modern Cemeteries. In: The archeology of death in post-medieval Europe (Tarlow, S., ed.), 170-188. Berlin.

BEKOVÁ, M., 2007: Solenice 2006, rkp. ulož. v ARÚ AV ČR, Praha, v. v. i., BZO 20071185 (383).

BERAN CIMBŮRKOVÁ, P., 2011: Antropologický rozbor kosterních pozůstatků z Rakovníka (kostel sv. Bartoloměje), ASČ 15, 1051-1062.

BLAŽKOVÁ-DUBSKÁ, G., 2005: Několik poznámek k archeologickému studiu novověkého pohřbívání v Čechách (Úvod ke studiu novověkých pohřebišt’ na Pražském hradě), Castrum Pragense 7, díl I.1, 201-216.

- 2005a: Archeologický výzkum novověkého pohřebiště u Jízdárny, Castrum Pragense 7, díl I.1, 403-410.

- 2006: Novověké pohřebiště v Jízdárně, Castrum Pragense 7, díl I.2, 145-174.

BLAŽKOVÁ, G.-OMELKA, M.-ŘEBOUNOVÁ, O., 2015: Death and burial in post-medieval Prague. In: The archeology of death in post-medieval Europe (Tarlow, S., ed.), 204-221. Berlin.

BOHÁČOVÁ, I., 2011: Pohřebiště na Loretánském náměstí v Praze-Hradčanech: archeologický výzkum Ivana Borkovského a jeho výsledky. Díl 1. Plány. Praha.

BOHÁČOVÁ, I.-BLAŽKOVÁ, G., 2011: Pohřebiště na Loretánském náměstí v Praze-Hradčanech: archeologický výzkum Ivana Borkovského a jeho výsledky. Díl 1. Textová část. Díl 2. Dokumentace. Praha.

BOYLE, A., 2015: Approaches to Post-medieval Burial in England: Past and Present. In: The archeology of death in post-medieval Europe (Tarlow, S., ed.), 39-60. Berlin.

BRESTOVANSKÝ, P., 2012: Devocionálie 17.-19. století v Čechách, Ročenka Jizersko-ještědského horského spolku $12,124-134$.

ČECHURA, M., 2010: Pohřební ritus ve středověku a novověku ve světle archeologického a antropologického výzkumu - Der Begräbnisritus im Mittelalter und der Neuzeit im Lichte der archäologischen und anthropologischen Forschung, AH 35, 111-120.

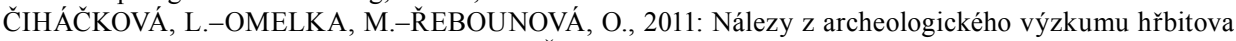
u kostela sv. Bartoloměje v Rakovníku, ASČ 15, 1029-1049.

DUDKOVÁ, V.-ORNA, J., edd., 2015: Od špitálu ke galerii... Archeologické poznání vývoje lokality „U Zvonu“" v Plzni. Plzeň.

- 2015a: Špitální kostel sv. Máří Magdalény. In: Od špitálu ke galerii... (Dudková, V.-Orna, J., edd.), 24-31. Plzen̆.

- 2015b: Po zrušení kostela a hřbitova. In: Od špitálu ke galerii... (Dudková, V.-Orna, J., edd.), 40-43. Plzeň. 
DUDKOVÁ, V.-ORNA, J.-NETOLICKÝ, P., 2015: Špitální areál sv. Máří Magdalény v Plzni. In: Od špitálu ke galerii... (Dudková, V.-Orna, J., edd.), 9-23. Plzeň.

FASSBINDER, S., 2003: Wahlfahrt, Andacht und Magie. Bonn.

FLEK, F. a kol., 2009: Flek, F.-Kubálek, P.-Omelka, M.-Podliska, J., Zahrada posledního odpočinku. In: Juřina, P. a kol., Náměstí Republiky. Výzkum století, 107-109. Praha.

- 2009a: Flek, F.-Kubálek, P.-Omelka, M.-Podliska, J., Excavation of the early modern cemetery of the grounds of the former Capuchin monastery at St. Joseph's in Prague's New Town - Výzkum novověkého hřbitova v areálu bývalého kláštera kapucínů u sv. Josefa v Praze - Novém Městě, Studies in Post-Medieval Archaeology 3, 407-452.

FRÁNA, J.- FIKRLE, M., 2007: Složení materiálů prstenů z bývalého hřbitova ve Šporkově ulici na Malé Straně, ASČ 11, 711-716.

- 2009: Materiál souboru kř́žžků ze zaniklého hřbitova při kostelu sv. Jana v Oboře (Praha-Malá Strana), ASČ 13, 1085-1093.

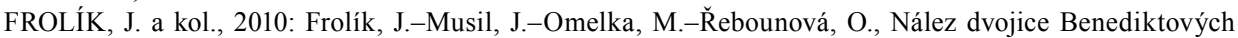
křižů z Chrudimi - Hradební ulice, Chrudimský vlastivědný sborník 14, 193-208.

GALETA, P. a kol., 2008: Galeta, P.-Sládek, V.-Sosna, D.-Čechura, M., 2008: Hodnocení distribuce izolovaných kostí na hřbitově u kostela sv. Ducha ve Všerubech: využití randomizačních metod. In: Počítačová podpora v archeologii 2 (Macháček, J., ed.), 61-75. Brno - Praha - Plzeň.

- 2015: Galeta, P.-Šneberger, J.-Friedl, L.-Pankowská, A.-Jurman, K., Antropologický rozbor. In: Od špitálu ke galerii... (Dudková, V.-Orna, J., edd.), 46-53. Plzeň.

- 2015a: Galeta, P.-Šneberger, J.-Friedl, L.-Pankowská, A.-Jurman, K.-Kubátová, I., Katalog kosterního souboru ze hřbitova u kostela sv. Máří Magdalény v Plzni. Plzeň.

GONZALES, J. M., 2015: Fashioning Death: Clothing, Memory and Identity in 16th Century Swedish Funerary Practice. In: The archaeology of death in post-medieval Europe (Tarlow, S., ed.), 111-124. Berlin.

HANUŠOVÁ, V., 2011: Pohřební ritus a hmotná kultura pohřebišt' 16.-19. století v Čechách, Acta FF ZČU, 52-67.

HANUŠOVÁ, V.-THOMOVÁ, Z., 2012: Pohřebiště a hmotná kultura u kostela sv. Mikuláše v Českých Budějovicích, AVJČ 25, 209-229.

HOLAS, M., 2016: Válečné hroby padlých v prusko-rakouské válce z roku 1866 na Královéhradecku v archeologickém kontextu. Bakalářská práce, Univerzita Hradec Králové.

CHROUSTOVSKÝ, L.-PRŮCHOVÁ, E., 2011: Classification of post-medieval secondary mortuary practices and disturbances, Interdisciplinaria archaeologica: natural sciences in archeology 2, 55-62.

JUŘINA, P. a kol., 2007: Předběžná zpráva o výsledcích plošného archeologického výzkumu v areálu bývalých kasáren Jiřího z Poděbrad na náměstí Republiky v letech 2003-2006, Archologica Pragensia 17, 211-232.

KACL, P.- PRU゚CHOVÁ, E.-RYTÍŘ, L., 2014: Lidé mezi hroby: o výzkumu zaniklého novověkého hřbitova v Praze-Karlíně. In: Veřejná archeologie 5: příspěvky z konference Archeologie a veřejnost 7/2013 (Bureš, M.-Šmejda, L.-Šmolíková, M., edd.), 92-97. Plzeň.

KELLER, P., Hrsg., 2008: Edelsteine \& Himmesschüre. Rosenkränze \& Gebetsketten. Salzburg.

- 2010: Glaube \& Aberglaube. Amulette, Medaillen \& Andachtsbildchen. Salzburg.

KENZLER, H., 2015: Religion, Status and Taboo. In: The archeology of death in post-medieval Europe (Tarlow, S., ed.), 148-169. Berlin.

KORENÝ, R.-OMELKA, M.-ŘEBOUNOVÁ, O., 2012: Př́íspěvek ke studiu devocionálií na Př́íbramsku, Podbrdsko XVIII, 260-277.

KOSTKA, M.-ŠMOLÍKOVÁ, M., 1998: Archeologický výzkum hřbitova u kostela sv. Klimenta v Praze-Bubnech. O pohřením ritu 19. století - Archaeological excavations in the cemetery at the Church of St Clement in Prague-Bubny; on 19th century burial rites, AR L, 822-836.

KOSTROUCH, F.-KODERA, P., 2010: Výzkum hřbitova u kostela sv. Jana Evangelisty v Blovicích - Die Ausgrabung des Friedhofs an der St. Johannes-Evangelist-Kirche in Blovice (Blowitz), AH 35, $183-202$.

KRAJÍC, R., 2007: Archeologie postmedieválního období. Současný stav a perspektivy výzkumu v jižních Čechách, Studies in Post-Medieval Archaeology 2, 57-96.

KRÁLÍKOVÁ, M., 2007: Pohřební ritus 16.-18. století na území střední Evropy. Brno.

KRYŠTŮFEK, F. X., 1898: Dějiny církve katolické ve státech rakousko-uherských s obzvláštním zřetelem k zemím Koruny české. Praha.

LAŠŤOVKOVÁ, B., 2006: Výzkum matrik zemřelých u kostela sv. Mikuláše na Malé Straně - s výtahem o pohřbených na hřbitově u sv. Jana v Oboře. In: Pražská pohřebiště a hřbitovy (Kašpar, V., ed.), 95-98. Praha. 
MELISCH, C. M.-ESCHER, F.-JUNGKLAUS, B., 2011: Der erste katholische Friedhof Berlins. Berlin.

MUIŽNIEKS, V., 2015: The Co-Existence of Two Traditions in the Territory of Present-Day Latvia in the 13th-18th Centuries: Burial in Dress and in a Shroud. In: The archeology of death in post-medieval Europe (Tarlow, S., ed.), 88-110. Berlin.

NOVÁČEK, K. a kol., 2010: Kladrubský klášter 1115-1421. Osídlení - architektura - artefakty. Dolní Břežany.

OMELKA, M., 2003: Archeologický výzkum ve Šporkově ulici čp. 332/III. In: Výroční zpráva 2002. Státní památkový ústav v hlavním městě Praze, 100-106. Praha.

- 2006: Sv. Jan v Oboře, Pražská pohřebiště a hřbitovy (katalog výstavy), 90-94. Praha.

- 2006a: Prezentace výsledků zpracování archeologického výzkumu ve Šporkově ulici čp. 322 na Malé Straně. In: Výroční zpráva NPÚ v hlavním městě Praze 2006, 77-78. Praha.

- 2006b: Nález neobvykle členěného medailonu s vyobrazením kříže svatého Benedikta a Zachariášova požehnání ze Šporkovy ulice čp. 332/III v Praze, Archeologica Pragensia 18, 144-152.

- 2009: Hřbitov u kostela sv. Jana v Oboře ve Šporkově ulici čp. 332/III na Malé Straně v Praze, Staletá Praha XXV, 93-101.

OMELKA, M.- STAREC P., 2002: Nové nálezy v areálu bývalého hřbitova u kostela sv. Jindřicha na Novém Městě pražském, Archaeologica Pragensia 16, 141-154.

OMELKA, M.-ŠLANCAROVÁ, V., 2007: Soubor prstenů ze zaniklého hřbitova při kostelu sv. Jana v Oboře (Praha-Malá Strana), ASČ 11, 671-709.

OMELKA, M.-̌̌EBOUNOVÁ, O., 2008: Soubor korálků ze zaniklého hřbitova při kostelu sv. Jana v Oboře (Praha-Malá Strana), ASČ 12, 605-679.

- 2011: Poznámky ke zbožnosti a pohřebnímu ritu malostranského barokního měštanstva ve světle archeologických nálezů, Pražský sborník historický XXXIX, 268-298.

- 2012: Soubor medailonů a feniků se symbolikou sv. Benedikta ze zaniklého hřbitova při kostelu sv. Jana v Oboře (Praha-Malá Strana), ASČ 16, 983-1019.

-2012a: A view of the archaeological context of the Lesser Town cemetery in Šporkova Street in Prague using Modern period iconography and written sources, Studies in Post-Medieval Archaeology 4, 233-250.

- 2014: Barokní mariánské kulty na Malé Straně v zrcadle pražských archeologických nálezů náboženských medailí (s přihlédnutím k situaci v Čechách a na Moravě), Pražský sborník historický XLII, 243-268.

- 2015: Rozbor hrobových nálezů duchovní povahy z novověkého pohřebiště u kostela sv. Máří Magdalény v Plzni. In: Od špitálu ke galerii... (Dudková, V.-Orna, J., edd.), 78-99. Plzeň.

- 2015a: Katalog náboženských medailek. In: Od špitálu ke galerii... (Dudková, V.-Orna, J., edd.), 100-110. Plzeň.

- 2015b: Katalog kř́žz̊u. In: Od špitálu ke galerii... (Dudková, V.-Orna, J., edd.), 112-122. Plzeň.

- 2016: Zboží pro chudé a bohaté -,originály“ a dobové „,padělky“ náboženských medailek na příkladu nálezů z hrobových kontextů - Ware für Arme und Reiche - „Originale“ und zeitgenössische „Fälschungen“ von religiösen Medaillen am Beispiel von Funden aus Grabkontexten, AH 41, 309-325.

OMELKA, M.-ŘEBOUNOVÁ, O.-MENOUŠKOVÁ, D., 2014: Novověká pohřební výbava ze sbírky Slováckého muzea v Uherském Hradišti a její vypovídací hodnota, Slovácko LVI, 151-175.

OMELKA, M.-̌̌EBOUNOVÁ, O.-ŠLANCAROVÁ, V., 2009: Soubor křížků ze zaniklého hřbitova při kostelu sv. Jana v Oboře (Praha-Malá Strana). I. Obecné formy kř́iže, ASČ 13, 1001-1083.

- 2010: Soubor křižků ze zaniklého hřbitova při kostelu sv. Jana v Oboře (Praha-Malá Strana). II. Speciální kříže, ASČ 14, 423-476.

- 2011: Špendlík - před hradbou a za hradbou - Die Stecknadel - vor und hinter der Stadtmauer, AH 36, 523-540.

OMELKA, M.-SELMI WALLISOVÁ, M., 2012: Nálezy z hrobů v ulici V Jirchářích na Novém Městě pražském, rkp. ulož. v archivu autorů, bez inv. č.

OMELKA, M.-ŠLANCAROVÁ, V., 2012: Nálezy šperků, devocionálií a součástí oděvů z kostela svatého Jakuba v Jihlavě, AVV 3, 75-132.

PETRÁŇ, J. a kol., 1995: Dějiny hmotné kultury II.1, 2. Kultura každodenního života od 16. do 18. století. Praha.

PILNÁ, V.-SCHMOLLOVÁ, J., 2014: Pohřební výbava Bohunky Lobkovické ze Šternberka ve sbírkách Západočeského muzea v Plzni, AZČ 8, 155-169.

PÍŠOVÁ, H., 2011: Distribuce izolovaných kostí v kumulaci na středověkém hřbitově ve Všerubech. Diplomová práce, Filozofická fakulta, Západočeská univerzita v Plzni. 
PRŮCHOVÁ, E., 2007: Pohřby nedospělých jedinců u kostela sv. Bartoloměje v Plzni, ŠZ AÚ SAV 42 , $153-162$.

PRŮCHOVÁ, E. a kol., 2005: Průchová, E.-Sládek, V.-Galeta, P.-Čechura, M., Nálezy fragmentů kostí na pohřebišti u kostela sv. Ducha ve Všerubech. In: Antropologické symposium IV. (Budil, I.-Horáková, Z.-Ulrychová, M., edd.), 269-281. Plzeň.

PǨIBIL, B., 1938: Soupis československých svátostek katolických medailí a jetonů. Numismatický časopis československý. Díl II. Čechy - Praha, 5-96. Praha.

- 2006: Medaile a svátostky k poctě sv. Václava. Soupis medailí a svátostek s obrazem sv. Václava i těch, jež s jeho kultem souvisejí, nebo světce vzpomínají (Kuchyňka, Z., ed.), Posel z Budče 23, 39-51.

RÍDL, J.-SLÁDEK, V., 2004: Využití aDNA v antropologických a archeologických výzkumech: limitující faktory. In: Antropologické symposium III (Budil I.-Horáková, Z., edd.), 265-278. Pelhřimov.

ŘEBOUNOVÁ, O., 2015: Pohřby na hřbitově při kostele sv. Máří Magdalény na základě písemných pramenů. In: Od špitálu ke galerii... (Dudková, V.-Orna, J., edd.), 32-39. Plzeň.

SOKOL, P., 2003: Šibenice v Bečově nad Teplou a archeologie popravišt' - The gallows at Bečov nad Teplou and the archaeology of places of execution, AR LV, 736-766.

- 2016: Šibenice u Přimdy. Archeologický výzkum objektu se zvláštním symbolickým a sociálním významem - Ein Galgen bei Přimda. Archäologische Ausgrabung eines Objektes von besonderer symbolischer und sozialer Bedeutung, AH 41, 501-523.

SLÁDEK, V.-GALETA, P.-SOSNA, D., 2012: Measuring human remains in the field: Grid technique, total station, or MicroScribe?, Forensic Science International 221, 16-22. DOI: https://doi.org/10.1016/j. forsciint.2012.03.018

SLÁDEK, V. a kol., 2008: Sládek, V.-Galeta, P.-Sosna, D.-Čechura, M., Metody terénní antropologie kosterních nálezů: hřbitov u kostela sv. Ducha ve Všerubech. In: Počítačová podpora v archeologii 2 (Macháček, J., ed.), 217-236. Brno - Praha - Plzeň.

SOSNA, D., 2007: Sekundární pohřební aktivity: srovnávací studie. In: Antropologické symposium V. Ústí nad Labem (Budil, I.-Zíková, T., edd.), 169-18. Plzeň.

SOSNA, D. a kol., 2013: Sosna, D.-Galeta, P.-Šmejda, L.-Sládek, V.-Brůžek, J., Burials and graphs: relations approach to mortuary analysis, Social Science Computer Review 31, 56-70. DOI: https://doi. org/10.1177/0894439312453277

SOUKUPOVÁ, H., 2011: Anežský klášter v Praze. Praha.

SOUQUET-LEROY, I.-RÉVEILLAS, H.-CASTEX, D., 2015: The Impact of Epidemics on Funerary Practices in Modern France (16th-18th Centuries). In: The archeology of death in post-medieval Europe (Tarlow, S., ed.), 61-87. Berlin.

SVATOŠ, L., 1928: Př́ručka církevní agendy. Praha.

ŠNEBERGER, J. a kol., 2015: Šneberger, J.-Pankowská, A.-Jurman, K.-Friedl, L.-Galeta, P., Př́ípadové studie. In: Od špitálu ke galerii... (Dudková, V.-Orna, J., edd.), 54-67. Plzeň.

TAGESSON, G., 2015: The Human Body as Material Culture - Linköping Cathedral Churchyard in the Early Modern Period. In: The archeology of death in post-medieval Europe (Tarlow, S., ed.), 19-38. Berlin.

TARLOW, S., 2015: Introduction: Death and Burial in Post-medieval Europe. In: The archeology of death in post-medieval Europe (Tarlow, S., ed.), 1-18. Berlin.

TRANBERG, A., 2015: Burial Customs in the Northern Ostrobothnian Region (Finland) from the Late Medieval Period to the 20th Century. Plant Remains in Graves. In: The archeology of death in post-medieval Europe (Tarlow, S., ed.), 189-203. Berlin.

UNGER, J., 2002: Pohřební ritus a zacházení s těly zemřelých v českých zemích (s analogiemi i jeden v Evropě) I. Panoráma biologické a sociokulturní antropologie 9 (Malina, J., ed.). Brno.

- 2002a: Pohřbívání v 16. století, SPFFBU C 49, 41-48.

- 2006: Pohřební ritus 1. až 20. století v Evropě z antropologicko-archeologické perspektivy. Panoráma biologické a sociokulturní antropologie 25 (Malina, J., ed.). Brno.

VALK, H., 2015: Tradition-based Concepts of Death, Burial and Afterlife: A Case from Orthodox Setomaa, South-Eastern Estonia. In: The archeology of death in post-medieval Europe (Tarlow, S., ed.), 125-147. Berlin.

WALDMANNOVÁ, M., 2015: Exkurz z pohledu památkové péče. In: Od špitálu ke galerii... (Dudková, V.Orna, J., edd.), 131-133. Plzeň.

ZEDNÍKOVÁ-MALÁ, P., 2015: Rekonstrukce přibližné podoby podle lebky. In: Od špitálu ke galerii... (Dudková, V.-Orna, J., edd.), 68-75. Plzeň. 


\section{Zusammenfassung}

\section{Stand und Perspektiven der Forschung bzgl. des neuzeitlichen Bestattungsritus in Böhmen}

Der Inhalt des vorliegenden Beitrags ist die Auswertung des Kenntnisstandes bzgl. neuzeitlicher Bestattungsareale in Böhmen (d.h. aus dem Zeitraum zwischen Ende des 15. bis zur ersten Hälfte des 20. Jahrhunderts) nach dem Jahr 2000 und basiert vor allem auf dem Studium der Fachliteratur (Unger 2002; 2006; Blažková-Dubská 2005, 201-216; Krajíc 2007, 57-96; Králíková 2007; Čechura 2010, 111-120; Hanušová 2011, 52-67; Blažková-Omelka-Řebounová 2015, 204-221; Juřina et al. 2007; Boháčová-Blažková 2011; Hanušová-Thomová 2012, 209-229; Dudková-Orna 2015 u.a.), auf den unveröffentlichen Ergebnissen der durchgeführten archäologischen Grabungen und auf den im System der Archäologischen Datenbank Böhmens erfassten Daten.

Im Vergleich mit der Situation vor dem Jahr 2000 kann man sagen, dass der Forschungsstand in Böhmen sich leicht zum Besseren gewendet hat was das Untersuchungsgebiet städtischer postmittelalterlicher katholischer Bestattungsbezirke betrifft. Das ist vor allem eine Folge dank einer systematischen interdisziplinären Bearbeitung des reichen Fundkomplexes vom Friedhof St. Johannes in Obora in der Šporkova-Straße in Prag (siehe z.B. Omelka 2006, 144-152; Omelka- ̌̌ebounová 2008, 605-679; 2012, 983-1019; 2012a, 233-250; 2016, 309-325; OmelkaŘebounová-Šlancarová 2009, 1001-1083; 2010, 423-476; 2011, 523-540; Omelka-Šlancarová 2007, 671-709) und des Komplexes von der Pilsener Fundstelle U Zvonu (Dudková-Orna 2015). Bei den an diesen Fundstellen durchgeführten archäologischen Grabungen wurde eine beträchtliche Fülle an osteologischem Material (Anzahl der anatomisch beigesetzten Individuen von der Grabung in der Šporkova-Straße - 906, von der Grabung an der Fundstelle U Zvonu - 219) und an Grabbeigaben der Verstorbenen erfasst. In beiden Fällen wurde sowohl eine detaillierte anthropologische Analyse, als auch eine gründliche Bearbeitung zumindest der wichtigsten Gruppen an Fundgegenständen durchgeführt (Rosenkränze, Kreuze, Kreuzanhänger, Medaillons). Gleichzeitig standen dort auch zeitgenössische schriftliche Quellen zur Verfügung, die dabei hilfreich waren, die Identität der Verstorbenen zu rekonstruieren und das Einzugsgebiet der Bestattungen oder die reale Auslastung der Bestattungsareale zu ermitteln.

Leider hat der Umstand immer noch Gültigkeit, dass eine Vertiefung der Kenntnisse über Aussehen und Veränderungen des Bestattungsritus in Böhmen durch den Charakter der durchgeführten archäologischen Grabungen beträchtlich eingeschränkt wird, die in überwiegender Mehrheit aus kleinen Rettungsgrabungen bestehen. Gemäß den aus der sog. Archäologischen Datenbank Böhmens gewonnenen Daten wurden in den Jahren 2000-2013 auf böhmischem Gebiet 252 archäologische Vorhaben realisiert, bei denen neuzeitliche Fundstellen (zwischen Ende 15. bis erste Hälfte 20. Jahrhundert) mit bestätigtem Vorkommen einer oder mehrerer Bestattungen erfasst wurden (Abb. 1), es jedoch lediglich bei ungefähr $12 \%$ von ihnen gelungen ist, über 15 Gräber zu erfassen (Abb. 2). Zu den größeren und potenziell sehr ergiebigen Grabungen zählen die in katholischen Bestattungsbezirken an der St. Nikolauskirche in České Budějovice (Hanušová-Thomová 2012, 209-229) und an der St. Nikolaus- und Elisabethenkirche in Eger, auf dem Bestattungsareal der Böhmischen Brüder bei Solnice in der Region Reichenau (16.-17. Jahrhundert, Beková 2007) oder auf dem Friedhofskomplex in Prag-Karolinenthal (18.19. Jahrhundert) durchgeführten Grabungen.

Die Entwicklung des Studiums des Bestattungsritus wird in Böhmen auch weiterhin durch den Mangel an Publikationen mit qualitativ gut bearbeiten Fundkomplexen gebremst. Eine große Herausforderung an die Forschung bleibt bislang auch die Untersuchung der sozialen Topographie der Bestattungsareale. Mit der gegebenen Problematik hängt auch zusammen, dass man die familiären Verbindungen zwischen den Gräbern oder die lokalen sozialen, kulturellen oder beruflichen Bestattungsbräuche oder die sozialen und demographischen Strukturen der Bestattungsbezirke nur unzureichend versteht. Als wünschenswert erscheint eine höhere Einbindung 
von historischen Analysen der schriftlichen Quellen und eine Vertiefung der Zusammenarbeit mit Fachleuten aus den naturwissenschaftlichen Disziplinen (Anthropologie, Genetik).

PhDr. Martin Omelka, Archiv hlavního města Prahy, Archivní 6, 14900 Praha 4, Česká republika, Martin.Omelka@praha.eu

Mgr. Otakara Řebounová, Archiv hlavního města Prahy, Archivní 6, 14900 Praha 4, Česká republika, Otakara.Rebounova@praha.eu 
